\title{
Religious Extracurricular as a Capital for Character Development of Students in Junior High School
}

\author{
Mahyudin Ritonga ${ }^{1}$, Ahmad Lahmi ${ }^{2}$, Ishaq ${ }^{3}$, Vini Wela Septiana ${ }^{4}$, Mahmud $^{5}$ \\ ${ }^{1,2,4}$ Muhammadiyah University of West Sumatera, Indonesia \\ ${ }^{3}$ Postgraduate Program, Muhammadiyah University of West Sumatera, Indonesia \\ ${ }^{5}$ Universitas Islam Negeri Imam Bonjol Padang, Indonesia
}

\begin{abstract}
The number of Islamic religious education hours in public school has not been able to keep up with the rapid development of technology, thus character building through intra curricular learning is inadequate, the adolescents who do not have sufficient filters to select information through various technological media, intra curricular insufficiency in character building extracurricular existence of students is increasingly needed. For the implementation of this research a qualitative approach was used, the data collection techniques used were observation, interviews and documentation, while the data analysis technique used was interactive. After analyzing the research data, it can be concluded that character values can be instilled in students through religious extracurricular programs. Another finding of this study was that the limited number of Islamic religious education hours in junior high schools that can be maximized through religious extracurricular activities.
\end{abstract}

Keywords:

Instiling, Character Education, Religious Extracurricular Activities

Article Received: 18 October 2020, Revised: 3 November 2020, Accepted: 24 December 2020

\section{INTRODUCTION}

Viewing the development of the character of the children today is very worrying. The character is an attitude and actions that emerge from the human beings positively and negatively (Yusuf et al., 2020). It can be seen that recently there are a lot of crimes developing among adolescents (Sumara et al., 2017). Crime occurs both in adolescence and adult hood (Indratmoko, 2017). In this case the researcher looked at the character among junior high school students, often fights, and even against their own parents. In this case there is no Islamic character seen among adolescents.

If the government does not take action and create a program, the adolescents will get worse in character for their future nationals. Both long-term and short-term programs. To solve this problem it should be instilled character education for child. Character education is seen as a solution to student behavior that is not in accordance with legal norms and disciplines in schools (Zulfarno et al., 2019), because character according to the demands of the 2013 curriculum should be integrated in every subject (Yusuf et al.,
2020). However, the reality that occurs in several integration education institutions has not been seen, character building and its relation to intra curricular seen as only Islamic religious education and citizenship (Hakim \& Ritonga, 2018) .

Extracurricular activities are learning and instilling character values for students (Alim et al., 2020). This is the improvement of education in cognitive area related to affective and psychomotor to facilitate the schooling and education in the family (Hakim et al., 2020).

Junior High School 39 Padang is not only a school that transfers knowledge only in the cognitive field, but schools also provide extracurriculars as a medium for character building. The purpose of this extracurricular activity is to train student' ability and courage. Besides training courage and abilities, it is also to improve the character of students, especially in the extracurricular religion field. All students are required to join one extracurricular. The extra-mandatory is Scout and the others is the option from the students themselves as, religion, paskibra, music, dance, and so forth. 
In accordance with the description of the problems described above, this study aimed to reveal the form of character value cultivation in extracurricular activities. So the main thing is extracurricular religious, while the forms of Islamic religious extracurricular is recitation of Asmual Husna, Quran, memorizing Qur'an, learning of read and write Quran, Muhadarah every Friday morning.

\section{Research methods}

As for performing this research, the researcher took the type of field research (field research ). It describes and tells the implementation in the field in accordance with reality, then the methods of the study used qualitative research methods. The qualitative method in research depends on the sharpness of the analysis, objectivity, systematic, not on the statistical point of calculating most of the truth in its interpretation. The data source in this study were from: 1) Primary data, namely 2 Islamic Religious Education teachers and assistant teachers, and 2) Secondary Data namely the Head of the school and student representatives. To obtain the correct data and maximum in a field study, we used a research tool, namely: 1) Observation, it looks directly into the monitoring field how implementation to activities of Islamic religious extracurricular with the purpose to know how to instil Islamic character of the program of religious extracurricular in Junior High School 39 Padang, 2) Interviews. Interview is collecting data with the form of question and answer directly in non formal. Documentation is the records of events.

The stages of data collection are as follows: Data reduction, namely grouping or organizing data, presenting data, namely conveying messages/information in conclusion form, drawing conclusions, namely the results of a research. Can in take the conclusion to analyze qualitative data that is by organizing data and presents it so it can concluded.

\section{Results Research and Discussion}

\section{Character building}

In Indonesian, the word "pendidikan" comes from word "didik", a word beginning with "pe and ending with " an ", that means" action "which has meaning (things, methods and so on) (Nurkholis, 2013). From the meaning of the word education according to the experts above, it can be concluded that education is a conscious effort to mature humans so that they can achieve the desired goals and become human beings with good character and ethics .

Character means someone who has a good attitude / behavior that always appears in a person. Someone who has the good character means that he acts of the principal that is always close to the Allah Almighty so that it can improve their potential (knowledge) and accompanied by consciousness, emotion and motivation (passion ), (Kamaruddin, 2012).

The definition above shows that the character is the behavior and actions of the customs of one life whether with the characteristics of honesty, hard work, simple as well as many others that always contains the value-the value of goodness or otherwise attitude / deed has value of evils that arise from a person .

Meanwhile, religious extracurricular activities are understood as activities in schools that are outside the formal curriculum related to religious fields and issues (Kurniawan, 2018). Extracurricular does not mean something apart with intra curricular, but the existence of extracurricular intended to encourage and support the realization of any goal planned in intra curricular (Craft, 2012), (Irawatie et al., 2019), (Suleiman et al., 2019).

Some of the views above show that religious extracurricular activities are an activity that exists in schools and is programmed to support the achievement of intra curricular goals. Religious activities have a wide scope, related to religious extracurricular activities in schools, in general, cannot be separated from fostering the reading and writing of the Koran, 
Rohis, memorizing al-Qur'an, muhadharah and al-Asma al-Husna reading activities.

\section{Character Education Values in Religious \\ Extracurricular Activities}

The values of character education that the authors discuss in this article are faith, good deeds, discipline and courage.

\section{Character of Faith}

Character is an attitude/action that comes from a person. In terms, faith is believe. It is as the term faith is a belief that is embedded in the heart, due to this belief there is a desire to say it orally, and it does not only stop there but it is also carried out in the form of actions by the limbs.

So that it is an act of faith character/behavior of someone who portray faith in God and not just believe but say the words and good deeds and ordered by God. As for the verse of the Quran which explains the faith of one can be seen in the statement of Allah whose mean "Except those who believe."

This verse tells about the losers of Allah that except those who have always believed in Allah and do all the commands and leave the prohibitions of Allah. Allah gives an exception from harm, to those who believe with their hearts, then that faith is expressed in good deeds. Tafsir Al-Mishbah explains that the meaning of faith in is to justify the heart for what was conveyed by the prophet Muhammad SAW (Shihab, 2008). This understanding leads to the fact that the verse of the Koran demands the possession of the six pillars of faith in the heart of every human being (Ritonga, 2016), (Ritonga, Asrina, et al., 2020).

According to the author, the meaning of Faith based on the meaning of the above verse is mentoring the heart, is described/mentioned in words and applied in everyday life in the form of actions. So a person who believes must have these 3 elements that are in line at once, namely heart, speech and actions that are always in line.

The characteristics of a believer according to these verses are: getting closer to Allah based on the word of Allah, QS Annisa 'verse 36: This means : "Worship Allah and associate nothing with Him, and to parents do good, and to relatives, orphans, the needy, the near neighbor, the neighbor farther away, the companion at your side, the traveler, and those whom your right hands possess. Indeed, Allah does not like those who are self-deluding and boastful". (Surah Annisa ': 36).

In this verse, there is an order to always obey Allah in affirming Allah and exalting Allah, and not confusing Allah with anything, be it statues, idols and others. A character of faith who is always obedient to Allah. It is evidenced by learning, reading and memorizing the Quran. Obeying is living the commands of Allah and His apostles.

\section{Character of Charity}

Pious charity is an act performed by someone that benefits himself as well as for others based on Islamic law. Because Allah will repay all human deeds, even though as big as the seeds of atom are done good eating will be rewarded by Allah and vice versa bad deeds are done as big as the seeds of atoms, Allah will reward that person a very painful punishment.

The practice of piousness has been explained in the Surah Al-'Ashr as a cut in the verse which means "doing good deeds and giving each other healthy." The word charity is described in the Qur'an as human power (Hidayat, 2017), reasonable minds, bodies, hearts for the use of human power, intellect, physical, heart, and vitality are done by humans and jinn. Word shalih drawn from the word shaluha who loved and liked by Allah (Shihab, 2008).

According to the Al-Mishbah, the intention of all acts of good deeds that are beneficial to himself and others is in accordance with the arguments of Islamic law. A mal righteousness referred to in the verse is the fruit of 
the faith of a servant who is obedient to Allah, which is then applied with good deeds .

According to the authors, performing good deeds that is stated by the verse above paragraph is to do good deeds that benefit themselves or others, based on Islamic law and sincere just because God alone. Good deeds are included in the commands of Allah SWT, because with righteous deeds a peaceful and happy life will be created. As Allah says in QS Al-Baqarah verse 82 , that means: "And those who believe and do good deeds, they are the inhabitants of heaven; they are eternal in it. " (QS Al-Baqarah: 82).

The goal is to carry out the commands of Allah and the Prophet, so that Allah will reward the heaven. The character of doing good deeds will be seen in children when they participates in religious extracurricular activities well, because the material is related to religion which makes a child an Islamic person and always does good deeds. The participation of students in religious extracurricular activities shows that the child already has the character of doing good deeds.

\section{Discipline Character}

Discipline is putting something in its place, or carrying out an activity that is carried out on time, according to its purpose and it does not come out of the rules that have been enforced. The symbol of discipline can be said as someone who obeys and obeys a rule. People who are always disciplined in terms of time, work and actions will symbolize a success in themselves (Yusuf et al., 2020), (Ritonga, Lahmi, et al., 2020). Because he respects his time and work.

Discipline is not a symbol of force or coercion to do a job. But discipline is a symbol of awareness and compassion in carrying out an activity. On the other hand, discipline that is carried out in the form of emotional, resentment and resentment will give birth to forced discipline

In religious extracurricular activities, it also forms a discipline character for students. In the implementation of compliance student to memorize al-Qur'an, regularly during the implementation. Activity of extracurricular religious conducted in the morning, then students should come to school on time and read juz amma and al-Quran. They all have to come quickly to school and dare to appear in front of guiding their friends. Students in the morning always gather at the Mosque Al-Bahri to offer dhuha prayers, and give alms according to their abilities and availability of the remaining finances that students have.

The results of the collection of charity by both teachers and students is a worship building although it is not as grand as places of worship in other places, the Al-Bahri mosque is the result of this donation coupled with the voluntary donations of every Muslim. The existence of this mosque for Junior High School 39 is a gift because even though it is still limited, students and teachers have been able to carry out worship in it even though they have to take turns, teachers and students carry out prayer in congregation at mosque, especially during Zuhur and Ashar.

\section{Efforts in building Students Character}

The environment has a tremendous influence on the formation of student character in addition to parental knowledge of religion. Negative environmental influences and the lack of knowledge about religion for parents and students cause character damage for most students. In addition, parents who are busy with work often make attention to children's development and behavior neglected. Therefore, at school, habituation has been programmed to recite Asmaul Husna and recite verses from the Koran after which it is closed with prayer recitations. We do this every morning under the guidance of student.

Junior High School 39 Padang begins make changes and instill religious values for the students. Every morning at the time of the first hour bells are rung for marching in the school grounds. At exactly 06.50 the bell was rung by the picket teacher and all the students 
gathered in the school yard. With a loud and firm voice uttered by Ismiarti, it makes the students more obedient to the applicable discipline.

After being neat and orderly in line up, this is the first step to instill religious values in students. The first step is that all students, teacher and principal are lining up at the same time on the school grounds to recite Asmaul Husna, who is led by the students. And then continued with the reading of Juz 30 which is also replaced until the student memorize it. Until the end, namely the prayer reading which is also led by students who have been trained before.

The morning activity is performed from 06.50-07.30 except Friday. Because on Fridays we have Muhadarah activities which are also rotated for each class. In the last December 2019 Mosque Al-Bahri is launched that is in the school environment. We built the letter with donations from teachers, student donations and parents' donations sincerely and without coercion.

In this way we can build the mosque even though it is only $80 \%$ ready. So now we can also use it. We also make a congregational prayer program for all students, even though it is only done alternately because the capacity of the prayer is only a few. The congregational prayer at Zuhur time is carried out by students entering the morning and the Ashar congregational prayer time is carried out by students entering the afternoon.

Meanwhile, religious extracurricular such as Tahfiz and PBTQ are held every Saturday, which is once a week. The companion consists of 2 people, namely 2 PAI teachers. Alhamdulillah, until now there are students who have memorized 1 juz and are starting to be able to read the Qur'an a little fluently for PBTQ extracurricular activities. It can be conclude from the implementation of the routine activities every morning at school, namely reciting Asmaul Husna, the verses of Allah with the prayers that are read out, it is clear that their effect is on students. One of them wis able to read Quran, read asmaul husna, start memorizing al-Qur'an.
Besides that, the results showed that training their courage to appear in front of their friends. Little by little they are brave and not awkward anymore. And most importantly the results we get are their discipline to come to school. From the religious extracurricular activities at Junior High School 39 Padang, there is an increase in the character values of children. The value of understanding about their own religion and awareness of their religious obligations. With this religious program students can increase their pious practices. Because there is a relationship between children who are diligent in reading the Quran and memorizing the Koran with their characters. Children who are always diligent in reading and memorizing the Koran will always maintain their attitude and character.

The implementation of the program, the activities of the morning routine is read Asmaul Husna, recite some verses from Holy Quran and prayers in trouble the first time we feel that put in order students in the march. But with a firm and courageous witness, everything can be overcome. Also this can be done because of our togetherness as another teacher council.

The research data described above showed its conformity with the research results disclosed by some researchers which emphasizes that student representatives have a significant role in enforcing student discipline (Eshetu, 2014), (Komariah \& Rohana, 2016). The results of other studies that support this research are findings that reveal that student representatives play an active role in fostering student behavior (Petriani \& Ananda, 2018), (Ritonga, Lahmi, et al., 2020).

Another reality that occurred at the research location was that the students were late in attending because they were lined up so quickly in the field. With the instruction of principle 1 for locking the gate clock at 07:05 a.m. then the policy to reduce students delay to attend in the morning. Because for students who are late, including teachers and principals even if it's late to be located in the outside of the fence until the first 
hour learning process ends performed in 7:30 to 08:10 a.m.

The challenges and obstacles faced in implementing muhadarah are limited places and locations. The location was in use just a school yard is limited, and students are asked to sit on the carpet that was developed throughout the school grounds during muhadarah process underway. As for the activity, there are no obstacles unless class representatives appear without prior preparation.

Muhadarah activities as carried out at Junior High School 39 Padang seem to provide satisfactory results in shaping the character of students, this statement is based on the results of observations which indicate a change in student behavior from the beginning of the study until the end of the study. Changes in the behavior and character of students cannot be separated from the material and content and advice given by the teacher at the end of the Muhadharah activity.

In accordance with the findings above, the results of this study appear to have similarities with Afrizal's conclusions which revealed that muhadharah activities can improve the students competence, the difference is seen in material objects where Afrizal's research focuses on improving the students skill (Afrizal \& Maulana, 2018). Other research results that have relevance to the findings of this study are the conclusions of Fauzi and Dja'far which emphasize that the Muhadharah activity program has an impact on improving the personality of students (Fauzi \& Dja'far, 2019), (Husna et al., 2020) .

As for the implementation of congregational prayers both zuhur and Asr have not been maximally carried out every day. Because those who do it are only students who are aware of their obligations as a Muslim, while other students, even though their prayer schedules have been determined, are more fun to play. This condition is inseparable from the condition of a small mosque so that students cannot be accommodated at the same time.

\section{Conclusion}

Based on the findings of researchers in the field, it can be seen that through religious extracurricular activities at Junior High School 39 Padang can improve student character values. From implementation of morning routine in the school, namely by reciting Asmaul Husna, reciting Quran and see the impact on students character learners. One of them is able to pronounce Asmaul Husna correctly, and learns how to memorize the Qur'an. Beside that results that is seen an increase and courage learners to show his ability in front of his friends.

\section{References}

[1] Afrizal, D., \& Maulana, A. (2018). Implementasi Kegiatan Muhadhoroh dalam Menumbuhkan Life Skill Siswa SMK Muhammadiyah 2 Gresik. Jurnal TAMADDUN-FAI UMG, XIX(1), 35-44.

[2] Alim, N., Ritonga, M., \& Mafardi. (2020). Korelasi Kegiatan Ekstrakurikuler Sanggar Al-Quran dengan Hasil Belajar Al-Quran Hadits di MAN 4 Pasaman Barat. Intiqa: Jurnal Agama Dan Pendidikan Islam, 12(2), 246-255. https://doi.org/10.30596/intiqad.v12i2.464 0

[3] Craft, S. W. (2012). The Impact of Extracurricular Activities on Student Achievement at the High School Level by.

[4] Eshetu, A. A. (2014). Indiscipline Problems of High School Students: the Case of Ethio-Japan Hidasse Secondary School (Addis Ababa, Ethiopia). Journal of Education and Practice, 5(37), 23-29.

[5] Fauzi, M. M., \& Dja'far, A. (2019). Implementasi Kegiatan Muhadharah dalam Meningkatkan Kepribadian Siswa di Pondok Pesantren Putri Babul Khairat Kertosari Pasuruan. PANCAWAHANA: Jurnal Studi Islam, 14(2), 123-134.

[6] Hakim, R., Khadijah, Ritonga, M., Susanti, W., \& Rahmi. (2020). Institute Quality Improvement Through Management Training of Accreditation Preparation in 
TK Aisyiyah Bustanul Athfal Padang. Advances in Social Science, Education and Humanities Research, Volume 449 Proceedings of the International Conference of Early Childhood Education (ICECE 2019), 44(Icece 2019), 55-65. https://doi.org/https://doi.org/10.2991/asse hr.k.200715.012

[7] Hakim, R., \& Ritonga, M. (2018). A Study of Religion Education Method With Multicultural Insight. International Seminar on Islamic Education (ISIE 2018) Faculty of Islamic Religion, Universitas Muhammadiyah Ponorogo, July 07th, 2018, Isie 2018, 81-97.

[8] Hidayat, R. (2017). Nilai-Nilai Psiko-Edukatif dalam Surat Al-'Ashr: (Pembacaan Kritis Atas Pemikiran M. Quraish Shihab dalam tafsir al-Misbah). Islamic Counseling, 1(02), 67-87.

[9] Husna, S. A., Ritonga, M., Lahmi, A., Saputra, R., \& Ayu, S. (2020). The Teachers Unpreparedness in Carrying Out Islamic Education Learning using the Revised 2013 Curriculum in Elementary School. European Journal of Molecular \& Clinical Medicine, 7(2), 1520-1528.

[10] Indratmoko, J. A. (2017). Pengaruh Globalisasi terhadap Kenakalan Remaja di Desa Sidomukti Kecamatan Mayang Kabupaten Jember. Citizenship Jurnal Pancasila Dan Kewarganegaraan, 3(1), 121-133.

http://e-journal.unipma.ac.id/index.php/citi zenship

[11] Irawatie, A., Iswahyuni, \& Setyawati, M. E. (2019). Education Learning Development of Character Education-Based State Defense. International Journal of Multicultural and Multireligious Understanding, 6(2), 27-42.

[12] Kamaruddin, S. A. (2012). Character Education and Students Social Behavior. Journal of Education and Learning, 6(4), 223-230.
[13] Komariah, N., \& Rohana. (2016). Peran Wakil Kepala Sekolah Bidang Kesiswaan dalam Meningkatkan Disiplin Siswa di Sekolah Menengah Atas (SMA) Muhammadiyah Tembilahan. AL-AFKAR, III(2), 79-143.

[14] Kurniawan, K. N. (2018). Tolerance Education in the Hidden Curriculum: A Case Study on Indonesian Public School. MASYARAKAT Jurnal Sosiologi, 23(1), 1-30. https://doi.org/10.7454/M

[15] Nurkholis. (2013). Pendidikan dalam Upaya Memajukan Teknologi. Jurnal Kependidikan, 1(1), 24-44.

[16] Petriani, E., \& Ananda, A. (2018). Peran dan Fungsi Wali Kelas dalam Pembinaan Perilaku Siswa di SMP Negeri 33 Padang. Journal of Civil Education, 1(3), 289-296.

[17] Ritonga, M. (2016). Bargaining Kata di Dalam Al Qur'an: Kontroversi Ahli Terhadap Bahasa al qur'an. AKADEMIKA: Jurnal Pemikiran Islam, 21(02), 229-254.

[18] Ritonga, M., Asrina, Widayanti, R., Alrasi, F., Julhadi, \& Halim, S. (2020). Analysis of Arabic Language Learning at Higher Education Institutions with Multi-Religion Students. Universal Journal of Educational Research, 8(9), 4333-4339. https://doi.org/10.13189/ujer.2020.080960

[19] Ritonga, M., Lahmi, A., Bambang, Ayu, S., Firdaus, Asmaret, D., \& Afdhal, S. (2020). Curriculum Development Strategy Management for Student Mental Health in Covid-19 Pandemic. International Journal of Pharmaceutical Research, 12(Spessial Issu 2), 4489-4494. https://doi.org/10.31838/ijpr/2020.SP2.562

[20] Shihab, M. Q. (2008). Tafsir Al-Mishbah Pesan, Kesan dan Keserasian Al-Qur'an (Issue 9). Lentera Hati.

[21] Suleiman, Y., Hanafi, Z., \& Muhajir, T. (2019). Influence of Extracurricular Services on Students' Academic Achievement in Secondary Schools in 
Kwara State: A Qualitative Approach. IJOLAE Indonesian Journal on Learning and Advanced Education, 1(2), 1-19. https://doi.org/10.23917/ijolae.v1i2.7766

[22] Sumara, D., Humaedi, S., \& Santoso, M. B. (2017). Kenakalan Remaja dan Penanganannya. Jurnal Penelitian \& PPM, 4(2), '129-389. http://journal.unpad.ac.id/prosiding/article/ viewFile/14393/6947

[23] Yusuf, M., Ritonga, M., \& Mursal. (2020). Implementasi Karakter Disiplin dalam Kurikulum 2013 Pada Bidang Studi PAI di SMA Islam Terpadu Darul Hikmah. Jurnal Tarbiyatuna, 11(1), 49-60. https://doi.org/https://doi.org/10.31603/tar biyatuna.v11i1.3437 Article

[24] Zulfarno, Mursal, \& Saputra, R. (2019). Aktualisasi Pendidikan Karakter dalam Pembelajaran Al-Islam dan Kemuhammadiyahan di SMA Muhammadiyah Kota Padang. Ruhama: Islamic Education Journal, 2(2), 117-131. 